\title{
Nitric oxide levels in the anterior chamber of vitrectomized eyes with silicon oil
}

\author{
Níveis de óxido nítrico na câmara anterior \\ em olhos vitrectomizados com óleo de silicone
}

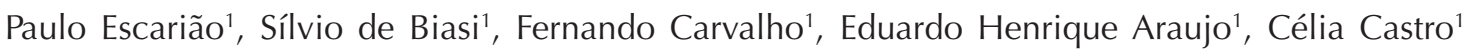

\begin{abstract}
Purpose: To investigate the nitric oxide levels in the anterior chamber of eyes who underwent pars plana vitrectomy (PPV) with silicone oil. Methods: Patients who underwent PPV with silicon oil injection, from february 2005 to august 2007, were selected. Nine patients (nine eyes) participated in the study (five women and four men). Nitric oxide concentration was quantified after the aspiration of aqueous humor samples during the procedure of silicon oil removal. Data such as: oil emulsification; presence of oil in the anterior chamber; intraocular pressure and time with silicone oil were evaluated. Values of $p<0.05$ were considered to be statistically significant. Results: A positive correlation between nitric oxide concentration and time with silicon oil in the vitreous cavity ( $r=0.799)$ was observed. The nitric oxide concentration was significantly higher $(p=0.02)$ in patients with silicon oil more than 24 months $(0.90 \mu m o l / m l \pm 0.59$, $n=3)$ in the vitreous cavity comparing to patients with less than 24 months $(0.19 \mu \mathrm{mol} / \mathrm{ml} \pm 0.10, n=6)$. Conclusion: A positive correlation linking silicone oil time in the vitreous cavity with the nitric oxide concentration in the anterior chamber was observed.
\end{abstract}

Keywords: Nitric oxide; Oxidative stress; Vitrectomy; Silicon oil; Glaucoma

\section{RESUMO}

Objetivo: Investigar os níveis de óxido nítrico na câmara anterior de olhos submetidos à vitrectomia via pars plana (VPP) com óleo de silicone. Métodos: Foram selecionados pacientes que se submeteram à VPP com injeção de óleo de silicone, de fevereiro de 2005 a agosto de 2007. Nove pacientes (nove olhos) participaram do estudo (cinco mulheres e quatro homens). Durante o procedimento de remoção do óleo de silicone, foi coletado uma amostra de humor aquoso para quantificar a concentração de óxido nítrico. Foram avaliados os seguintes dados: emulsificação de óleo, presença de óleo na câmara anterior, pressão intraocular, tempo com o óleo de silicone. Valores de $\mathrm{p}<0,05$ foram considerados estatisticamente significativos. Resultados: Foi observada uma correlação positiva entre a concentração de óxido nítrico e tempo com óleo de silicone na cavidade vítrea $(\mathrm{r}=0,799)$. A concentração de óxido nítrico foi significativamente maior $(\mathrm{p}=0,02)$ em pacientes com óleo de silicone por mais de $24 \mathrm{meses}(0,90 \mu \mathrm{mol} / \mathrm{ml}+0,59, \mathrm{n}=3) \mathrm{na}$ cavidade vítrea em comparação com pacientes com menos de 24 meses $(0,19 \mu \mathrm{mol} / \mathrm{ml}+0,10, \mathrm{n}=6)$. Conclusão: Foi observada correlação positiva entre tempo de óleo de silicone na cavidade vítrea com a concentração de óxido nítrico na câmara anterior.

Descritores: Óxido nítrico; Estresse oxidativo; Vitrectomia; Óleo de silicone; Glaucoma

1. Department of Retinal and Vitreous Diseases, Fundação Altino Ventura e Hospital de Olhos de Pernambuco - Recife (PE), Brazil.

The authors declare no conflicts of interest

Recebido para publicação em 9/7/2012 - Aceito para publicação em 21/11/2012

Rev Bras Oftalmol. 2013; 72 (5): 326-30 


\section{INTRODUCTION}

$\mathbf{G}$ laucoma is a possible complication in patients who underwent posterior pars plana vitrectomy (PPV) with silicon oil injection. Its frequency has been reported between 5.9 and $56 \%^{(1)}$. Aphakia, steroids use and previous vitreoretinal surgery have been described as risk factors for glaucoma in patients who underwent PPV with silicon oil injection ${ }^{(2)}$. After removal of the silicon oil, the intraocular pressure can continue high due to possible structural damage to the trabecular meshwork ${ }^{(1-9)}$.

Experimental studies demonstrated that silicon oil acts as a barrier to the diffusion of oxygen, maintaining a high oxygen concentration in the anterior chamber ${ }^{(10-16)}$. The oxygen tension in the anterior chamber is higher in eyes treated with lensectomy/ vitrectomy using silicon oil than in eyes just treated with lensectomy/vitrectomy ${ }^{(10)}$. There are no prior studies in humans that reveal the relation of free oxygen radicals in the anterior chamber of vitrectomized eyes with silicon oil.

The purpose of this study was to evaluate the nitric oxide levels, related to oxidative stress, in the anterior chamber of patients who underwent PPV with silicon oil injection.

\section{Methods}

A prospective and analytical study was developed in the Department of Retina and Vitreous of the Altino Ventura Foundation and in the Laboratory of Immunopathology Keizo Asami (LIKA) - Pernambuco Federal University.

Patients who underwent PPV with silicon oil injection, from february 2005 to august 2007 were selected. Nine patients (nine eyes) participated in the study, five women and four men. The oil emulsification, presence of oil in the anterior chamber, intraocular pressure elevation (above $21 \mathrm{mmHg}$ ) and time of permanence of the oil in the eye were evaluated.

The diagnosis requiring silicon oil injection was retinal detachment with proliferative vitreoretinopathy in eight cases and proliferative diabetic retinopathy in one case. Six patients were pseudophakic, two aphakic and one phakic.

During the surgery of silicon oil removal and before the approach to the posterior segment, $0.2 \mathrm{ml}$ of aqueous humor was aspirated with a paracentesis using an insulin syringe $(1 \mathrm{ml})$. The material was transferred to a sterile recipient, and then the nitric oxide concentration was quantified with the Griess reagent, that provides a well characterized assay for nitrites and nitrates. Nitric oxide is readily oxidized to nitrite and nitrate. Thus, the Griess reagent can indirect measure the nitric oxide concentration, quantifying the amount of nitrite.

The study was conducted after approval by the Ethics Committee of the Altino Ventura Foundation. All patients signed a consent form. The statistical tests used for continuous variables data were the non-parametric Mann-Whitney test and the Pearson correlation coefficient, to measure the linear dependence of two variables: nitric oxide concentration and time with silicon oil. The level of statistical significance was $\mathrm{p}<0.05$.

\section{Results}

The data such as subject age, lens status, previous pathology, emulsification, presence of oil in the anterior chamber, ocular hypertension (above $21 \mathrm{mmHg}$ ) and time permanence of the silicon oil are described in table 1.

A positive correlation was observed between the nitric oxide concentration and the permanence time of silicone oil in the vitreous cavity $(\mathrm{r}=0.799, \mathrm{p}=0.01)$.

To compare nitric oxide concentration and emulsification (table 2), oil in the anterior chamber (table 3), intraocular pressure and silicon oil time (table 4), the Mann-Whitney test was used.

There is a statistically significant difference $(\mathrm{p}<0.05)$ between the mean values of the nitric oxide concentration in patients with less than 24 months duration of silicone oil and those over 24 months (table 4).

\section{Discussion}

The morphological and physiologic alterations in aqueous humor drainage, in glaucoma patients, have oxidative stress as a contributor factor. The trabecular meshwork is exposed to free oxygen radical species in the aqueous humor from the aerobic metabolism, and from the mechanical stress ${ }^{(17-20)}$. The damage to the trabecular meshwork cells could lead to an intraocular pressure elevation and glaucoma ${ }^{(17-19)}$.

Reactive oxygen species generated by oxidative stress include: superoxide, hydrogen peroxide, hydroxyl and nitric oxide. The greater accessibility to quantify in the material studied is nitric oxide. The achievement of aerobic metabolism occurs with

Table 1

Patient's data who have undergone PPV with silicon oil injection

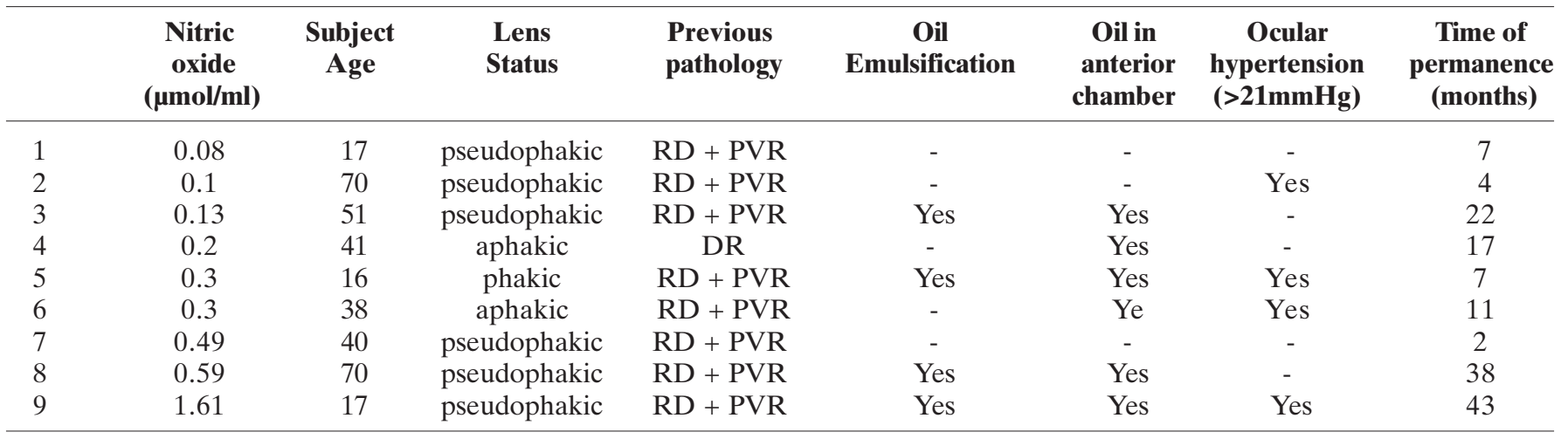

RD: retinal detachment; PVR: proliferative vitreoretinopathy; DR: diabetic retinopathy 
Table 2

Comparison of nitric oxide concentration and emulsification $(p=0.176)$

\begin{tabular}{lcccccc}
\hline & & \multicolumn{5}{c}{ NO concentration $(\boldsymbol{\mu m o l} / \mathbf{m l})$} \\
\cline { 3 - 7 } Oil emulsification & $\mathbf{n}$ & Mean & $\begin{array}{c}\text { Standard } \\
\text { deviation }\end{array}$ & Median & Minimum & Maximum \\
\hline No & 5 & 0.23 & 0.17 & 0.20 & 0.1 & 0.5 \\
Yes & 4 & 0.66 & 0.66 & 0.44 & 0.1 & 1.6 \\
Total & $\mathbf{9}$ & $\mathbf{0 . 4 2}$ & $\mathbf{0 . 4 8}$ & $\mathbf{0 . 3 0}$ & $\mathbf{0 . 1}$ & $\mathbf{1 . 6}$ \\
\hline
\end{tabular}

$\mathrm{NO}=$ nitric oxide

Table 3

Comparison of nitric oxide concentration and presence of silicone oil in the anterior chamber $(p=0.195)$

\begin{tabular}{lcccccc}
\hline & & \multicolumn{5}{c}{ NO concentration $(\boldsymbol{\mu m o l} / \mathbf{m l})$} \\
\cline { 3 - 7 } Oil in anterior chamber & $\mathbf{n}$ & Mean & $\begin{array}{c}\text { Standard } \\
\text { deviation }\end{array}$ & Median & Minimum & Maximum \\
\hline No & 3 & 0.22 & 0.2 & 0.10 & 0.1 & 0.5 \\
Yes & 6 & 0.52 & 0.56 & 0.30 & 0.1 & 1.6 \\
Total & $\mathbf{9}$ & $\mathbf{0 . 4 2}$ & $\mathbf{0 . 4 8}$ & $\mathbf{0 . 3 0}$ & $\mathbf{0 . 1}$ & $\mathbf{1 . 6}$ \\
\hline
\end{tabular}

$\mathrm{NO}=$ nitric oxide

Table 4

Comparison of nitric oxide concentration and intraocular pressure $(p=0.461)$; Comparison of the nitric oxide concentration and time with silicone oil $(p=0.020)$

\begin{tabular}{|c|c|c|c|c|c|c|}
\hline \multirow[b]{2}{*}{$\begin{array}{l}\text { Intraocular pressure } \\
\text { (>21 mmHg) }\end{array}$} & \multirow[b]{2}{*}{$\mathbf{n}$} & \multicolumn{5}{|c|}{ NO concentration $(\mu \mathrm{mol} / \mathrm{ml})$} \\
\hline & & Mean & $\begin{array}{l}\text { Standard } \\
\text { deviation }\end{array}$ & Median & Minimum & Maximum \\
\hline No & 4 & 0.51 & 0.74 & 0.17 & 0.1 & 1.6 \\
\hline Yes & 5 & 0.36 & 0.48 & 0.30 & 0.1 & 1.6 \\
\hline Total & 9 & 0.42 & 0.48 & 0.30 & 0.1 & 1.6 \\
\hline Time with oil (month) & $\mathbf{n}$ & Mean & $\begin{array}{l}\text { Standard } \\
\text { deviation }\end{array}$ & Median & Minimum & Maximum \\
\hline$<=24$ & 6 & 0.19 & 0.10 & 0.17 & 0.1 & 0.3 \\
\hline$>24$ & 3 & 0.90 & 0.62 & 0.59 & 0.5 & 1.6 \\
\hline Total & 9 & 0.42 & 0.48 & 0.30 & 0.1 & 1.6 \\
\hline
\end{tabular}

$\mathrm{NO}=$ nitric oxide

mitocondrial oxidative phosforylation and production of highly reactive metabolites of oxygen as the radical superoxide, that when interacting with nitric oxide forms the peroxynitrite, which is a strong oxidant. Nitric oxide and its metabolites interact with reactive oxygen species leads to protein nitration, which is one of the chemical modifications that occur during oxidative stress $^{(21)}$.

The oxidative stress causes an injury to the trabecular meshwok through reduction of protease activity, a multicatalytic complex responsible for cellular protection, yielding reduction of cellular viability implicated in glaucoma physiopathology ${ }^{(19)}$. The damage to the trabecular meshwork due to free oxygen radicals is well established in previous studies ${ }^{(22-24)}$. Nitric oxide is also responsible to damage the ganglionar cells in the retina, and for the intraocular pressure elevation ${ }^{(25)}$.

Posterior vitrectomy can modify the gradient of oxygen concentration in the vitreous cavity ${ }^{(26,27)}$. When the vitreous gel is present and intact there is a diffusion of oxygen from the retinal arterioles into the vitreous and then, an uptake of this oxygen by the retinal tissue ${ }^{(27)}$. Before vitrectomy, the oxygen appears to be higher around the circumference of the vitreous body. After vitrectomy, the fluid in the vitreous cavity can mix freely and the oxygen concentration near the lens increases greatly ${ }^{(27)}$. So, the surgery increases oxygen concentration in the vitreous cavity, increasing the concentration of free oxygen radicals ${ }^{(26)}$. The lens exposure to these free radicals is a mechanism of cataract formation ${ }^{(27)}$. Pseudophakic or aphakic patients could have an increase concentration of free oxygen 


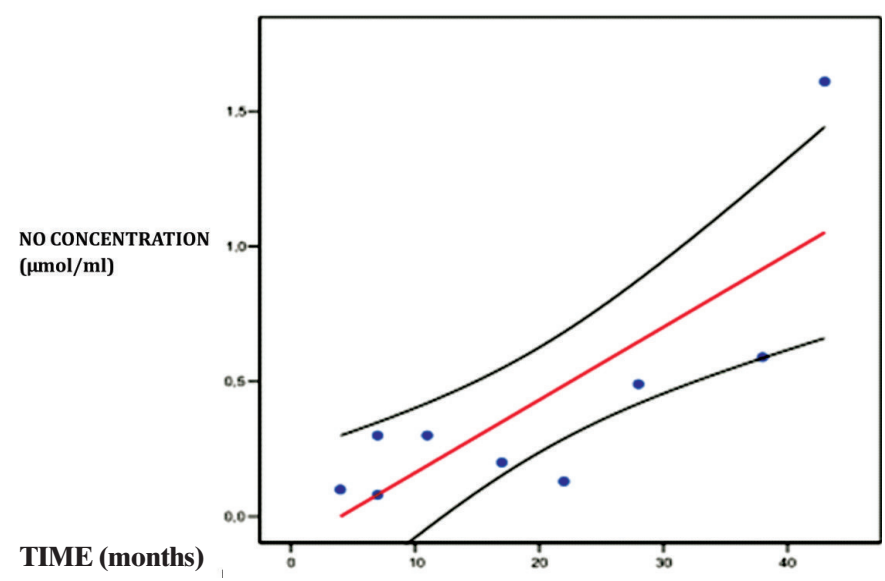

Figure 1: Dispersion between the nitric oxide (NO) concentration and the silicon oil time; $(-)$ best line of linear regression with the confidence interval $(-) ; \mathrm{r}=0.799(\mathrm{p}=0.010) ; \mathrm{r} 2=0.638$

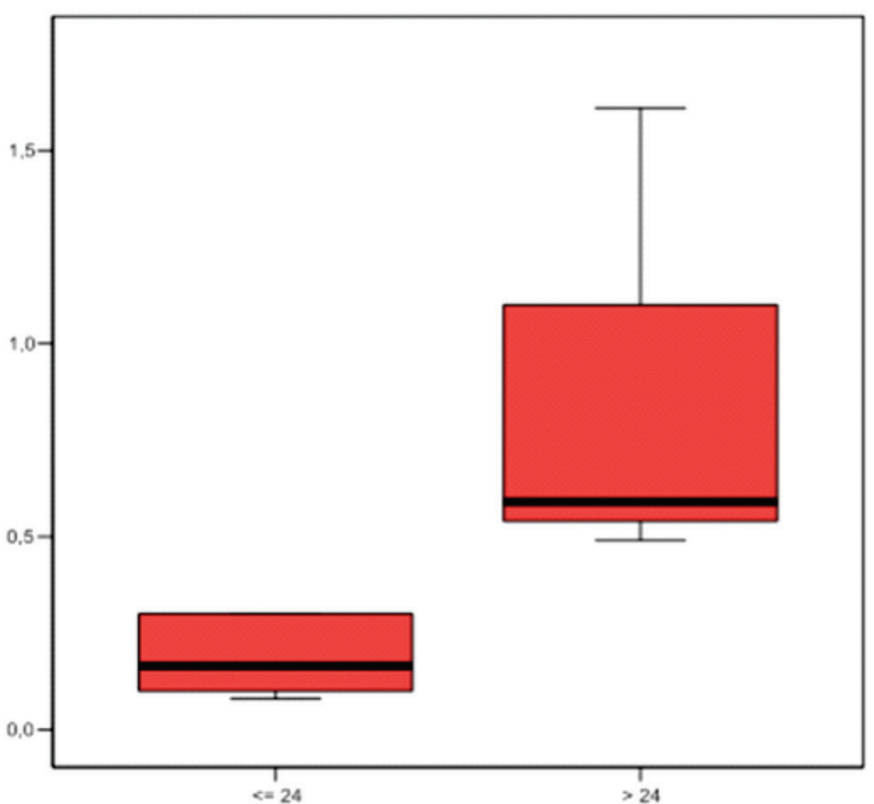

Figure 2: Box plot (median, $25^{\text {th }}$ and $75^{\text {th }}$ percentiles) from two groups: less than 24 months duration and more than 24 months

radicals in the anterior chamber with possible structural damage to the trabecular meshwork cells and the development of glaucoma as considered by Chang ${ }^{(28)}$. The oxidative stress has been implicated as a possible cause of glaucoma in vitrectomized patients, due to injury to the trabecular meshwork cells and intraocular pressure elevation ${ }^{(28)}$.

The silicon oil has been used as a vitreous substitute in complex retinal detachment cases. It may lead to some complications as secondary open angle glaucoma, cataract and corneal decompensation. The silicon oil in the vitreous cavity acts as a barrier to the oxygen diffusion, increasing its concentration in the anterior chamber ${ }^{(10-16)}$. The presence of silicon oil in the eye could change the oxygen tension in the anterior chamber, leading to an increase of nitric oxide concentration and oxidative stress. Pseudophakic and aphakic patients would be more likely to have increased levels of oxygen free radicals in the anterior chamber due to the lens absence and its capacity to metabolize the excess oxygen.

Patients with proliferative diabetic retinopathy also have increased levels of nitric oxide when compared to diabetics without retinopathy ${ }^{(29)}$. These patients would be at increased risk to develop greater oxidative stress and possibly glaucoma when submitted to vitrectomy with silicon oil.

This study revealed a correlation between the duration of silicon oil in the eye and the oxide nitric concentration, suggesting an oxidative stress increase in the anterior chamber of these patients. This oxidative stress increase could lead, in a time period not well known, to damage to the trabecular meshwork and intraocular pressure elevation, thus a new mechanism of glaucoma in silicon oil patients.

The development of glaucoma was not observed in any patient of this study during the follow up time. This finding could be associated to the sample size and requirement of a larger follow up time.

\section{Conclusion}

The study observed a correlation between time with silicon oil in the vitreous cavity and nitric oxide levels in the anterior chamber.

\section{ReFERENCES}

1. Gedde SJ. Management of glaucoma after retinal detachment surgery. Curr Opin Ophthalmol. 2002;13(2):103-9. Review.

2. Al-Jazzaf AM, Netland PA, Charles S. Incidence and management of elevated intraocular pressure after silicone oil injection. J Glaucoma. 2005;14(1):40-6.

3. Detry-Morel M. [Glaucoma secondary to surgery of the posterior eye segment]. Bull Soc Belge Ophtalmol. 2003;(288):65-74. French.

4. Budenz DL, Taba KE, Feuer WJ, Eliezer R, Cousins S, Henderer J, et al. Surgical management of secondary glaucoma after pars plana vitrectomy and silicone oil injection for complex retinal detachment. Ophthalmology. 2001;108(9):1628-32.

5. Montanari P, Troiano P, Marangoni P, Pinotti D, Ratiglia R, Miglior M. Glaucoma after vitreo-retinal surgery with silicone oil injection: epidemiologic aspects. Int Ophthalmol. 1996-1997;20(1-3):29-31.

6. Orticio LP. Silicone oil-induced secondary glaucoma: a case study. Insight. 2000;25(2):44-9.

7. Suic SP, Sikic J.The effect of vitrectomy with silicone oil tamponade on intraocular pressure and anterior chamber morphology. Coll Antropol. 2001;25 Suppl:117-25.

8. Rice TA, Michels RG, Maguire MG, Rice EF. The effect of lensectomy on the incidence of iris neovascularization and neovascular glaucoma after vitrectomy for diabetic retinopathy. Am J Ophthalmol. 1983;95(1):1-11.

9. Bartz-Schmidt KU, Thumann G, Psichias A, Krieglstein GK, Heimann K. Pars plana vitrectomy, endolaser coagulation of the retina and the ciliary body combined with silicone oil endotamponade in the treatment of uncontrolled neovascular glaucoma. Graefes Arch Clin Exp Ophthalmol. 1999;237(12):969-75.

10. de Juan E Jr, Hardy M, Hatchell DL, Hatchell MC. The effect of intraocular silicone oil on anterior chamber oxygen pressure in cats. Arch Ophthalmol. 1986;104(7):1063-4.

11. Stefansson E,Landers MB 3rd, Wolbarsht ML.Vitrectomy, lensectomy, and ocular

12. Barbazetto IA, Liang J, Chang S, Zheng L, Spector A, Dillon JP. Oxygen tension in the rabbit lens and vitreous before and after vitrectomy. Exp Eye Res. 2004;78(5):917-24. 
13. McLaren JW, Dinslage S, Dillon JP, Roberts JE, Brubaker RF. Measuring oxygen tension in the anterior chamber of rabbits. Invest Ophthalmol Vis Sci. 1998;39(10):1899-909. Erratum in Invest Ophthalmol Vis Sci. 1999;40(12):2779.

14. Helbig H, Noske W, Kellner U, Foerster MH. [Oxygen in the anterior chamber before and after cataract operation]. Ophthal-mologe. 1995;92(3):325-8. German.

15. Fitch CL, Swedberg SH, Livesey JC. Measurement and manipulation of the partial pressure of oxygen in the rat anterior chamber. Curr Eye Res. 2000;20(2):121-6.

16. Stefansson E, Peterson JI, Wang YH. Intraocular oxygen tension measured with a fiber-optic sensor in normal and diabetic dogs. Am J Physiol. 1989;256(4 Pt 2):H1127-33.

17. Zhou L, Li Y, Yue BY. Oxidative stress affects cytoskeletal structure and cell-matrix interactions in cells from an ocular tissue: the trabecular meshwork. J Cell Physiol. 1999;180(2):182-9.

18. Wright G, Terada K, Yano M, Sergeev I, Mori M. Oxidative stress inhibits the mitochondrial import of preproteins and leads to their degradation. Exp Cell Res. 2001;263(1):107-17.

19. Caballero M, Liton PB, Epstein DL, Gonzalez P. Proteasome inhibition by chronic oxidative stress in human trabecular meshwork cells. Biochem Biophys Res Commun. 2003;308(2):346-52.

20. Tezel G. Oxidative stress in glaucomatous neurodegeneration: mechanisms and consequences. Prog Retin Eye Res. 2006;25(5):490-513.

21. Masri F. Role of nitric oxide and its metabolites as potential markers in lung cancer. Ann Thorac Med. 2010;5(3):123-7

22. Nguyen KP, Chung ML, Anderson PJ, Johnson M, Epstein DL. Hydrogen peroxide removal by the calf aqueous outflow pathway. Invest Ophthalmol Vis Sci. 1988;29(6):976-81.
23. Kahn MG, Giblin FJ,Epstein DL. Glutathione in calf trabecular meshwork and its relation to aqueous humor outflow facility. Invest Ophthalmol Vis Sci. 1983;24(9):1283-7.

24. Chen JZ, Kadlubar FF. A new clue to glaucoma pathogenesis. Am J Med. 2003;114(8):697-8. Comment on Am J Med. 2003;114(8): 638-46.

25. Saccà SC, Pascotto A, Camicione $\mathrm{P}$, Capris $\mathrm{P}$, Izzotti A. Oxidative DNA damage in the human trabecular meshwork: clinical correlation in patients with primary open-angle glaucoma. Arch Ophthalmol. 2005;123(4):458-63.

26. Barbazetto IA, Liang J, Chang S, Zheng L, Spector A, Dillon JP. Oxygen tension in the rabbit lens and vitreous before and after vitrectomy. Exp Eye Res. 2004;78(5):917-24.

27. Holekamp NM, Shui YB, Beebe DC. Vitrectomy surgery increases oxygen exposure to the lens: a possible mechanism for nuclear cataract formation. Am J Ophthalmol. 2005;139(2):302-10.

28. Chang S. LXII Edward Jackson lecture: open angle glaucoma after vitrectomy. Am J Ophthalmol. 2006;141(6):1033-43.

29. Tsai DC, Chiou SH, Lee FL, Chou CK, Chen SJ, Peng CH, et al. Possible involvement of nitric oxide in the progression of diabeticretinopathy. Ophthalmologica. 2003;217(5):342-6.

\section{Author Corresponding:}

Paulo Escarião, MD, MBA

Altino Ventura Foundation, Department of Ophthalmology, 170

- Soledade St

Zip code 50040-070 - Recife (PE) Brazil

Phone: (81) 33024300

Email: phescariao@hotmail.com 